\title{
Local People Attitudes towards Community Forestry Practices: A Case Study of Kosti Province-Central Sudan
}

\author{
Amani Abdel Rahim Kobbail \\ Department of Social Forestry, College of Forestry and Range Science, Eltakamul, P.O. Box 6146, Khartoum 11113, Sudan \\ Correspondence should be addressed to Amani Abdel Rahim Kobbail, amanyforest@yahoo.com
}

Received 18 May 2011; Accepted 11 September 2011

Academic Editor: Piermaria Corona

Copyright ( $) 2012$ Amani Abdel Rahim Kobbail. This is an open access article distributed under the Creative Commons Attribution License, which permits unrestricted use, distribution, and reproduction in any medium, provided the original work is properly cited.

\begin{abstract}
This paper examines the attitudes of local communities toward community forestry programmes implemented by a project under the CF approach in Kosti area, based on a survey of 100 people living there. The household was the basic unit of data collection; ten villages were selected as study localities. Ten respondents from each village were randomly chosen for the interview. Frequency distribution results showed that almost all the respondents have a particularly favourable perception of the community forestry programmes implemented and they perceive the best type of management for running these forests which is to be owned and managed by them. They participated in different programe activities and willing to further participation in tree planting activities. Women have possessed positive attitudes towards community forestry although they were not fully involved in community forestry Practices. Stepwise multiple linear regression analysis showed a statistical significant relation between some selected variables (Respondents age, educational level, main occupation, respondents indigenous knowledge, family uses of different forestry products, awareness of causes of forest destruction and finally respondents awareness of environmental problems) exerted important influences on the attitudes and participation of respondents. This study suggests that the project and the forest services should continue addressing local development needs, encourage women's participation in community forestry, and work toward dispute settlement of community forest-user groups, if it wants to win the support of local communities for long-term environmental conservation goals.
\end{abstract}

\section{Introduction}

It is estimated that the natural forests of the Sudan occupies about $23 \%$ of the total land area. The average annual increment of growing stock volume is about 1.340 million cubic meter of which $5 \%$ is removed (67 million cubic meters) per a year. The majority 57 million cubic meters is used for firewood and charcoal, while 9\% cubic meter is used for high quality timber, the rest is lost because of fires, drought, overgrazing, and agricultural practices.

Next to the firewood collection, the most important forest activity is gum production, which also has pivotal value to the national economy. Gum Arabic tree, namely, Acacia senegal and Acacia seyal species are the most important species in low rainfall savannah belt extending between latitudes $10^{\circ}$ and $14^{\circ} \mathrm{N}$. The area of natural gum belt is estimated to cover 520,000 square kilometers roughly one fifth of Sudan's total area [1]. The gum gardens form a traditional bush fallow farming system in which bush fallow and cereal and gum trees rotate. Seven to ten years of fallow period is enough for the Acacia senegal to regenerate and the soil to regain its fertility. In 1970s, the ecological balance of this system is disrupted. Because of the pressure of growing population and consequent demand for cereals, the fallow part of the cycle was reduced. In the accelerated cycle, Acacia senegal trees can no longer regenerate and deforestation results.

It is clear that this situation will become increasingly critical as time goes on. In many places, trees have been totally cleared around the settlements. In these subsistence economies, the presence of forest beyond walking distance to household is of often irrelevant. Furthermore, there has been increasing recognition that local communities must be actively involved, and their needs and aspirations considered if resources are to be conserved [2-9]. Social forestry or 
community forestry has been gaining attention as one of the solution to the ever present energy crisis in the rural areas of developing countries [10-12]. All policies and programmes implemented under the community forestry paradigm share a key assumption that resource conservation will succeed only if local communities receive sufficient benefits, participate in management, and, therefore, have a stake in conserving the resource [13-15]. In the recent years; Sudan has implemented the concept under the term rural tree planting.

\section{Objectives of the Study}

The main objective of this study is to examine the attitudes of local communities toward community forestry programmes implemented by a project under the CF approach in Kosti area. Another objective was to determine demographic and socioeconomic variables influence these attitudes.

\section{Methodology}

The study was undertaken in Kosti province of White Nile area of Central Sudan (see Figure 1). The climate of the area is semiarid, with an average rain fall of $250-350 \mathrm{~mm}$. The main physiognomic vegetation type is woodland savannah which generally reflects the semiarid climate. The vegetation is characterized by several Acacia species of which important multipurposes species. The area is inhibited both by settled and nomadic population, their economy is dominated by traditional rain fed agriculture and seasonal wages.

3.1. Data Sources. The data were collected from both primary and secondary sources. Primary data were obtained through both formal and informal interviews. For formal interviews, a questionnaire for basic information at the household level was designed prior the fields work to collect both qualitative and quantitative information. The questionnaire was first tested in the field with 20 heads of households. The questionnaire was adequate and very slight modifications were made to suit the conditions of the study area. The questionnaire was administered to hundred heads of households from the selected villages. All interviews with respondents were carried out in Arabic language although the questionnaire was setup in English. These interviews were accompanied by personal observations which allowed the author to judge the reliability of the answers given. Selection of villages was done according to the distribution of the existing community forestry. Ten villages were covered and they represent Kosti North Rural Council. All are the target villages of Sudan-Finland White Nile Rural Forestry Programme. In all selected villages, the village leader was the first to be approached and talked to about the purpose of the visit and the study to get permission to carry out interviews with the respondents. The questionnaire was designed to obtain information on personal characteristics of the respondents, economic activities and environmental aspects in addition to respondent attitude towards community forestry activities.

Informal interviews Include discussion with the village leaders, extension workers, and personal observations from

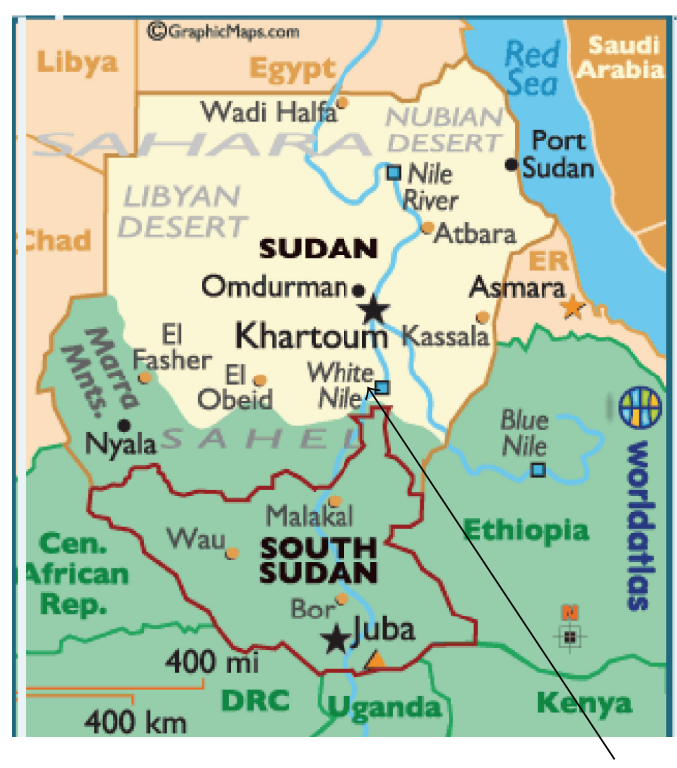

The study area

Figure 1: Map of the Sudan.

the field visits were the methods used to collect qualitative information. Observations were found to be useful in collecting information on physical aspects such as vegetation and soil. It was also found useful in directing attention to certain aspects of human behaviour especially where there were different tribes in the area, which showed different pattern of life.

Secondary data were obtained largely through the analysis of various documents relevant to the study. This includes institutional reports, records, and papers which provide baseline information for the study. The institutions from which the data was collected are directly involved in the study, such as the Forest National Corporation, Sudan-Finland White Nile Forestry Programme, Social Research Statistics, and Veterinary and Agriculture Departments. Also information was gathered from reports and files found at Kosti area and Rural councils.

3.2. Data Analysis. Data were analyzed using the Statistical Package for the Social Sciences (SPSS) Version 11. Calculation of the percentage was used as a tool of analysis for interpreting of the qualitative information gathered from respondents. Regression analysis was also used as an analytical tool in this study. In this statistical approach, stepwise multiple linear regression analysis was used to explain the influence of some selected variables expected to affect the dependent variables. To determine whether such demographic and socioeconomic variables as gender, age, education, main occupation respondents indigenous knowledge, family uses of different forestry products, awareness of causes of forest destruction, and finally respondents awareness of environmental problems helped explain why some respondents held more favourable attitudes than others toward community forestry, this analysis was used because under the practical situation community forestry activities are probably 
influenced by many factors. Respondents' attitude towards community forestry activities, attitudes towards tree planting, and participation in community forestry are taken as the dependent variables. The independent variables influencing community forestry activities at household level taken in this part include respondents age, educational level, main occupation, respondents indigenous knowledge, family uses of different forestry products, awareness of causes of forest destruction, and finally respondents awareness of environmental problems.

The correlations of determination $\left(R^{2}\right)$ were computed. This measures the strength of the linear relationship between the dependant and independent variable(s).

\section{Results and Discussions}

4.1. Socioeconomic Characteristics of the Respondents. One hundred respondents completed the survey (86\%) men and (14\%) women were interviewed. The above percentage does not imply that there are more men than women in the study area.

In the rural areas of the Sudan, man is the chief earner of income and is responsible for supply of food and the most essential requirements of living for his family. Therefore, as a rule men are to be interviewed since they are heads of the households and in charge of the major land use activities. The role of women in the rural areas is to supply water, collection of fuelwood, cooking, looking after the children, and carrying out other domestic affairs. The small proportion of the female respondents is those whose husbands are absent.

The age of respondents ranged from 30 to 50 years, with a median age of about 35 years, primarily rural workers $(70 \%$ farmers, $30 \%$ other jobs). Of those who revealed no regular education are 55\%. Those who have received khalwa (Quran education), primary, intermediate, and secondary educational levels are very few; their percentages are 2\%, 21\%, $8 \%$, and $14 \%$, respectively. Most of the respondents $(89 \%)$ are not members of any type of social committees. They were not government employees and never practiced any form of leadership (Sheik 4\%, member of village committee $4 \%$, and member of rural town council $3 \%$ ).

\subsection{Respondents' Indigenous Knowledge System about Forestry}

4.2.1. Knowledge about Trees and Tree Uses. The survey showed that respondents are knowledgeable about different types of trees species and know which of them are appropriate and even know how to propagate them. As stated by them most of these trees were dominant in the area and disappeared over the past 20 years due to extensive forest cutting with exception of mesquite (Prosopis chilensis), which is newly introduced in the area. In this survey, Hashab (Acacia senegal) trees were recognized by most of the respondents $(83 \%)$ than any other type of trees. This is mainly because the White Nile area is one of the most important gum production areas of the Sudan followed, by siddir (Ziziphus spina christi) (80\%) then heglig (Balanites aegyptiaca) (74\%) and talh (Acacia seyal) (72\%). Neem (Azadirachta indica) and tundub (Capparis decidua) are recognized by few respondents
$14 \%$ and $18 \%$, respectively. This showed the majority of the respondents are aware of specific trees around them.

The majority of the respondents perceived trees as valuable and useful resources. They can identify many uses of trees, all of which were important in their daily life. This indicates a high level of awareness about the value of trees. It also reveals how people are dependent on these valuable resources. Based on the results of this survey, trees are most useful to respondents as a source of firewood (73\%) to provide energy for the daily needs. The second use of trees most often mentioned by the respondents was as a source of construction material (54\%). Thirty-five percent of the respondents also perceive the benefit that trees provide in terms of shade protection from heat and sand. The fourth use of trees identified by the respondents is as a source of charcoal (20\%), while $11 \%$ of the respondents mentioned the use of trees for fodder and fencing and only $8 \%$ mentioned that trees are source of fruits.

4.2.2. Causes of Forest Damage. All respondent felt that land in the White Nile is highly degraded and recognized this as a problem. Thus the majority of the respondents $52 \%$ mentioned that natural drought is the most destructive agent of the forest, while $51 \%$ of the respondents related forest degradation to illegal cuttings and removal of trees. Fourteen percent of the respondents believed that, grazing is one of the causative agents of forest degradation. Generally the misuse of the soil and the natural vegetation by over exploitation for fuel, shifting cultivation, and overgrazing leads to serious erosion by wind and water. According to Stebbing [16] and Ayoub [17], the misuse of the natural resources leads to irregularity or intermittency and reduction in rainfall and such conditions do not favor any form of productive cultivation and the only possible use is grazing. With increasing numbers of animals and decreasing grazing resources, the land falls progressively into stark desert conditions. People are aware by the causes of forest destruction; heavy extension efforts are needed to highlight people awareness about the causes of damage to reduce forest degradation and encourage tree planting.

4.3. Attitudes towards Community Forestry Activities. The present survey results shows that most of the respondents are aware of the productive and the protective role of trees, and they express their urgent need to plant trees to combat the threatening environmental problems and to provide them with fodder and other useful tree products. All communities have developed positive attitudes towards tree planting as $100 \%$ of the respondents believe that trees preserve soil fertility and reduce the land susceptibility to wind and water erosion. $99 \%$ of the respondents explained that tree planting secure their future and trees should be planted to meet their personal requirements. Moreover, $98 \%$ of the respondents explained that their villages need more trees and $90 \%$ of the respondents are interested in growing trees in their farm. It is obvious that establishment of community forestry in the area is socially acceptable. This new conviction of the positive attitudes towards tree planting should receive higher 
attention from the forestry extensionists and should be exploited for further development of new programmes.

Most of the respondents of the surveyed villages possess positive attitudes towards community forestry activities; $73 \%$ of the respondents believed that community forestry represents a source of fodder for grazing particularly in the dry season and they totally depend on them. The majority of villagers depend on these community forests for grazing. Forty-nine percent of the respondents reported that community forestry supported them with firewood, and $48 \%$ of the respondents appreciated the vital role of these forests in protecting them from desertification and they stated that the establishment of these forests has slowed down the movement of sands towards villages. Forty percent of the respondents recognized the protective role of these forests against wind blowing and $16 \%$ of the respondents viewed these forests as a source of beauty, pleasure, and landscape, and this is an interesting answer from the respondents to feel the aesthetic value of these forests. As a conclusion all the respondents benefit from these forests. Their benefits range from satisfying basic domestic needs to complete use for grazing. It is safe to say that community forestry play an increasing economic role in communities' life. This role has not been appreciated in the past, due to the abundance of forest resources as perceived by such communities. At present, all communities appreciate this role.

Respondents' acceptance of community forestry is very clear in the study area and almost all of them 99\% prefer that these forests to be owned and managed by them. They reported the importance of having link with the forest department and this in fact is a reflection of the positive attitude of local people towards the forest department. They prefer that the role of forest department lies in coordination, technical roles, and implementation of laws. The majority of the respondents thought that this is the best way to ensure participation, protect forests from damage, and illegal use. This was a very useful result which shows the change in the rural people attitude towards forestry and forest department. Also this result indicates a change in the feeling of fear that the forest department will take their lands and the difficulty of management if these forest are left to people alone.

The survey results showed that the majority of the respondents (91\%) participated in the major tasks of community forestry that is, planting operations which include land preparation (digging of pits), watering, seedling transportation, cleaning, and so forth. Thirty-four percent of the respondents participated in maintenance and protection of these forests, while $25 \%$ contributed mainly in form of ideas and organization. Generally establishment of plantation under the custody of forest department should be done with very significant involvement of local people. This will provide the people with the opportunity of joint responsibility with the forest department in the process of establishment of plantations and hence help them to develop a sense of belonging to the plantations and perceive them as their own assets designed to solve some of their felt needs. From the informal discussion carried with the interviewed women, it is clear that in the surveyed villages, men play a central role in tree planting and women are not fully involved in tree growing in the surveyed area. The lack of active participation and proportional representation of women in community forestry programme, however, needs to be addressed. Women are most involved in collecting forest products, and, therefore, their role in managing community forests is important.

Most of the respondents express their readiness and willingness to participate in forest management. The form of contribution ranges from minimum of cash and efforts (6\%) to a maximum of any type of contribution to be asked. The demanding experience of the self-help programmes, adopted by government to tap community resources for provision of basic services, is the main reason that makes people not to commit themselves for cash contributions. They opt for easy riding option of any other form of contribution. Provision of efforts accounts for 7\% only of the total respondents. Responses to contribution to help in planting the sandy land to be allotted for forest are expressed by $61 \%$ of the respondents. Some of the respondents indicated their readiness to plant trees in their farm land $(22 \%)$, while $9 \%$ of the respondents are willing to give part of their land. Women were found to have positive attitudes towards community forestry activities, and they are willing to participate in community programmes activities.

In assessing the degree of influence of some selected variables expected to affect the ultimate-dependent variables (Attitude towards community forestry, attitude towards tree planting, and respondents participation in community forestry practices), stepwise linear multiple regression technique is used. All the dependent variables were regressed on respondents' age, education level, main occupation, environmental problems awareness, causes of forest damage, family uses of trees, and local people indigenous knowledge. Attitude towards community forestry and respondents participation, in addition to the above-mentioned independent variables, are regressed on attitude towards tree planting. Some of these variables do not enter in the models.

Regression results (Table 1) show that as expected, causes of forest damage, respondents' indigenous knowledge and respondents' attitude towards tree planting have positive influence on respondents' attitude towards community forestry activities. The regression coefficients of these independent variables are highly significant at $<0.01$ level of significant. Gender has negative influence on the dependent variable. The regression coefficient of gender is significant at 0.02 level of significant. The coefficient of determination $\left(R^{2}\right)$ of the model is 0.28 . Table 2 showed the comparison of the means.

By examining the effect of these independent variables on respondents' attitude towards tree planting, the results of regression analysis technique (Table 3 ) show that family uses of trees and age were found to have highly significant positive effect on the dependent variable $(P<0.01)$ with explanatory power $\left(R^{2}\right)$ equal to 0.15 . Table 4 showed the comparison of the means.

When respondents attitude towards tree planting replaced in the model by respondents participation in community forestry activities and regressed on the same independent variable, the regression results (Table 5) show that, causes of forest damage and gender positively influence the 
TABLE 1: Effect of some selected variables on respondents' attitude towards community forestry.

\begin{tabular}{lccc}
\hline Dependent variable & Independent variable & Regression coefficient & $P$ \\
\hline Attitude towards & Causes of forest damage & +0.511 & 0.004 \\
community & Indigenous knowledge & +0.1745 & 0.006 \\
forestry & Attitude towards tree & +0.3307 & 0.007 \\
& Gender & -0.7517 & 0.02 \\
\hline
\end{tabular}

$R^{2}=0.28(F=9.51 ; P=0.0001)$.

TABLE 2: Comparisons of means for the selected variables affect the dependent variable (respondents' attitude towards community forestry).

\begin{tabular}{|c|c|c|c|c|c|c|}
\hline Independent variables & No. of sample & Sum of squares & Df & Mean square & $F$ & Sig. \\
\hline Gender & 100 & 46.95 & 4 & 11.73 & 9.51 & 0.0001 \\
\hline Attitude towards tree & 100 & 38.66 & 3 & 12.88 & 9.85 & 0.0001 \\
\hline Causes of forest damage & 100 & 40.43 & 3 & 13.477 & 10.45 & 0.0001 \\
\hline Indigenous knowledge & 100 & 42.92 & 4 & 10.73 & 8.40 & 0.0001 \\
\hline
\end{tabular}

TABLE 3: Effect of age and family uses on attitude towards tree planting.

\begin{tabular}{llll}
\hline $\begin{array}{l}\text { Dependent } \\
\text { variable }\end{array}$ & $\begin{array}{l}\text { Independent } \\
\text { variables }\end{array}$ & $\begin{array}{l}\text { Regression } \\
\text { coefficient }\end{array}$ & $P$ \\
\hline $\begin{array}{l}\text { Attitude towards } \\
\text { tree }\end{array}$ & Family uses & +0.2382 & 0.002 \\
\hline
\end{tabular}

$R^{2}=0.15(F=8.95 ; P=0.0003)$.

dependent variable at $<0.01$ level of significant. The coefficient of determination $\left(R^{2}\right)$ is 0.18 . Table 6 showed the comparison of means.

The negative significant effect of gender on respondents' attitude towards community forestry obtained from the data analysis results could be attributed to the fact that women are active users and managers of forests and tree resources, but as forestry is considered a man's field, women's roles are often invisible to project designers and to policy makers. Women are involved in all aspects of fuelwood use, and they are primary collectors of fuel wood. Their use of forest resources extends beyond consumption of fuel wood. They are involved in many activities which use forest products. This includes their participation in agriculture, animal husbandry, handicraft production, and use of woody plants for medicinal purposes. It is clear that, women play a significant role in the use of forest resources, and they possess highly positive attitude towards community forestry activities rather than men. They have a high level of awareness of local forest and the useful products that it provides.

Respondents' indigenous knowledge was found to affect their attitudes towards community forestry activities positively. This result is expected for intuition that, farmers know trees and how to grow them and they have done it on their own initiatives since before colonial times. They know which local species are appropriate and useful; no foresters had taught them how to grow trees. Their information about the values and the use of trees is important in forming their positive attitude towards trees and forests.
The statistical positive relationship of causes of forest damage and respondents attitude towards tree planting and attitude towards community forestry activities concord with the increasing knowledge of farmers about their environment which gained through a continuous process resulting from practical experiences, past events, observations, experimentation, local culture, and traditions. And with respondents' appreciation of the increasing economic role of tree planting which had not been felt in the past due to abundance of forest resources but now all communities appreciate this role and their feelings are positive. Deforestation and consequent need to plant more trees; clearly "community forestry" is most accurately and clearly understood as an umbrella term denoting a wide range of activities link rural people with forests and trees and the product and benefit to drive from them, hence affect their attitude.

Ages proved to have a positive significant effect on respondents attitude towards tree planting; this could be explained by the migration of the youth to the nearest cities seeking employment to improve their financial situation leaving only older men and women in the villages hence all burden of farming and planting of trees felt on them. The significant positive influence of family uses of trees on the respondents attitude towards tree planting could be explained by the importance and usefulness of trees to respondents and total dependence of the rural people upon the outputs of trees and forests in their vicinity and the usage which falls broadly into direct use by the household, such as fuelwood and food; inputs into the agricultural system such as fodder and mulch; sources of income and employment. Rural people awareness about the important and magnitude of the tree products improve their attitude towards tree planting activities.

Causes of forest damage proved to have a positive significant effect on respondents participation, this could be explained by the general argument that farmers know very well that over exploitation of forests eventually leads to the total depletion of tree resources in addition to the fact that they live in real scarcity conditions regarding forest product 
TABLE 4: Comparisons of means for the selected variables affect the dependant variable (respondents' attitude towards tree).

\begin{tabular}{lcccccc}
\hline Independent variables & No. of sample & Sum of squares & Df & Mean square & $F$ & Sig \\
\hline Family uses & 100 & 7.97 & 1 & 7.97 & 9.92 & 0.002 \\
Age & 100 & 13.52 & 2 & 6.76 & 8.95 & 0.0003 \\
\hline
\end{tabular}

TABLE 5: Effect of age and cause of forest damage on respondents' participation.

\begin{tabular}{llll}
\hline Dependent variable & Independent variables & Regression coefficient & $P$ \\
\hline Participation & Causes of forest damage & +0.3197 & 0.0004 \\
& Gender & +0.4600 & 0.0070 \\
\hline$R^{2}=0.18(F=10.96 ; P=0.0001)$ & &
\end{tabular}

$R^{2}=0.18(F=10.96 ; P=0.0001)$.

TABLE 6: Comparisons of means for the selected variables affect the dependent variable (Participation).

\begin{tabular}{lcccccr}
\hline Independent variables & No. of sample & Sum of squares & Df & Mean square & $F$ & Sig \\
\hline $\begin{array}{l}\text { Causes of forest } \\
\text { damage }\end{array}$ & 100 & 5.01 & 1 & 5.01 & 13.67 & 0.0004 \\
\begin{tabular}{l} 
Gender \\
\hline
\end{tabular} & 100 & 7.55 & 2 & 3.77 & 10.96 & 0.0001 \\
\hline
\end{tabular}

particularly fuelwood which has manifested the economies in fuel use and even reduction in cooking. Farmers feel that their life characterized by urgent general scarcity of daily necessities. Due to all that, tree growing is shown as an appropriate response to those pressures. The importance of forest and forest products in the daily life of farmers had encouraged them to participate in community forestry activities.

Results of data analysis revealed that, among the selected variables expected to affect participation, gender has positive significant effect on participation. This could be attributed to the fact that, men play a central role in tree planting and women were not fully involved in tree growing in the surveyed villages. As argued by Skutch [10], women, unlike men, do not take up tree planting. The author further stressed that men, whose authority is not easily changeable retain the sole right to grow, manage, and fell trees. In the rural areas of Sudan, women are almost a part of household resources, their chief role being reproduction and caring for the family, fetching water, cooking food, and procuring fuelwood. Decision about how fuelwood gathered and used are made by women inside the family. Also the seasonal migration phenomenon has placed a heavy burden on women especially in the study area, only the children and old men are left behind in the village; the women's role in agricultural production has increased. It has been found in some countries that, men could successfully claim ownership of land if they had planted trees on the disputed land. Trees planted by individual could, therefore, lead to land ownership, and since women were not allowed to own capital assets they could not plant trees $[18,19]$. This claim was not evident in the case of the surveyed villages. It was noted that women tend to prefer working alone on their own pieces of land within the family fields which are usually smaller than those of men particularly where cash crops are grown. Women farmers who plant trees are mostly those who own land mainly through the Islamic law of inheritance. However, women claim that they are usually very busy. Particularly, during the peak periods of the agricultural season they become more stressed and their time becomes more limited.

It is safe to say women would have been interested in getting cheap fuelwood, and tree planting may, therefore, be better tended. The problem is family duties constraints. Attention should be given to the role of women in household economy. Heavy extension efforts are needed for women about collaboration in tree planting and how to be compatible with family duties.

\section{Conclusions and Future Directions}

This study concluded the following.

(1) Respondents' reflect similar constituencies who hold similar views toward tree planting and community forestry, and they do share a common understanding of the condition and dynamics of the environment and the forest resources.

(2) People of the study area are knowledgeable by different types of species and aware of the benefits of trees and community forestry. There is also a general agreement and consensus about the value of trees for wood supply and protection. They possess positive attitude towards tree planting and community forestry.

(3) Rural people acceptance to these community forestry is very clear and they perceive the best type of management for running these forests which is to be owned and managed by them.

(4) A combination of different factors, connected to community forestry practices, influences attitudes toward tree planting and community forestry in our study.

The study recommended the following.

(1) Increasing local awareness and knowledge about rights along with improving relationships between 
the local community and forest stewards has to be a priority for further community forestry practices.

(2) To forage ahead with community forestry programmes and their implementation foresters should develop a two-way communication system with farmers. They should be involved in problem definition, the design of possible solutions, and evaluation of the proposed technological solutions. We also need to encourage local people to share their good ideas with us so that we can support their initiatives and develop village extension plans based on these.

(3) Extensionists should treat farmers as people with valuable information and knowledge about the local environment. This knowledge is vital for providing insights on how the needs of people can be met, which includes maintaining sound environmental conditions.

(4) Women should be involved in community forestry programmes as decision makers and implementers as the wood collection and consumption is their responsibility, and they remain in the villages all year round. Women play a vital role in tree planting programmes as they show interest, positive attitude, and willingness to participate.

\section{References}

[1] FAO, "Culinary and aromatic plants in the near east," in Proceedings of the International Expert Meeting, Food and Agriculture Organization of the United Nations, Cairo, Egypt, May 1999.

[2] S. R. Kellert, "Social and perceptual factors in endangered species management," Journal of Wildlife Management, vol. 49, no. 2, pp. 528-536, 1985.

[3] A. Fletcher, "Parks, protected areas and local populations: new international issues and imperatives," Landscape and Urban Planning, vol. 19, no. 2, pp. 197-201, 1990.

[4] P. C. West, "Introduction," in Resident Peoples and National Community-based conservation in Makalu-Barun, 1991.

[5] M. Gadgil, "Conserving biodiversity as if people matter: a case study from India,” Ambio, vol. 21, no. 3, pp. 266-270, 1992.

[6] J. A. McNeely, Parks for Life: Report of the IVth World Congress on National Parks and Protected Areas, IUCN, Gland, Switzerland and Cambridge, UK, 1993.

[7] C. Lewis, Managing Conflicts in Protected Areas, IUCN, Gland, Switzerland and Cambridge, UK, 1996.

[8] A. A. Kobbail, Towards a participatory management of forest reserves in Sudan: a case study of ElRawashda and Elain Natural Forests, Ph.D. thesis, University of Khartoum, Khartoum, Sudan, 2005.

[9] M. Triguero-Mas, M. Olomí-Solà, N. Jha, F. ZorondoRodríguez, and V. Reyes-García, "Urban and rural perceptions of protected areas: a case study in Dandeli Wildlife Sanctuary, Western Ghats, India," Environmental Conservation, vol. 36, no. 3, pp. 208-217, 2009.

[10] M. Skutch, Why People Do not Plant Trees, Village Case Studies. Tanzanian Resource for Future, Washington, DC, USA, 1983.

[11] E. A. Elsiddig, N. Goutbi, and B. Elasha, Community Based Natural Resource Management in Sudan, Intergovernmental Authority on Development, Khartoum, Sudan, 2003.
[12] E. K. Glover, Tropical dry land rehabilitation: case study on participatory forest management, Ph.D. thesis, Viikki Tropical Resource Institute, University of Helsinki, Gedref, Sudan, 2005.

[13] C. C. Gibson and S. A. Marks, "Transforming rural hunters into conservationists: an assessment of community-based wildlife management programs in Africa," World Development, vol. 23, no. 6, pp. 941-957, 1995.

[14] A. M. Osman, Joint management of natural forest reserves in Sudan: a case study ELRawashda natural forest reserve, M.S. thesis, University of Khartoum, Khartoum, Sudan, 2000.

[15] L. Wily, "Participatory forest management in africa. An overview of progress and issues," in Proceedings of the 2nd International Workshop on Participatory Forestry in Africa, 2002.

[16] E. P. Stebbing, The creeping Desert in the Sudan and Elsewhere in Africa, Sudan Government Printing Press, 1953.

[17] A. T. Ayoub, "Extent, severity and causative factors of land degradation in the Sudan," Journal of Arid Environments, vol. 38, no. 3, pp. 397-409, 1998.

[18] M. Arnold, Community Forestry. Ten Years in Review, FAO, Rome, Italy, 1992.

[19] M. Arnold, Managing Forests as A common Property, no. 136, FAO, Rome, Italy, 1998. 

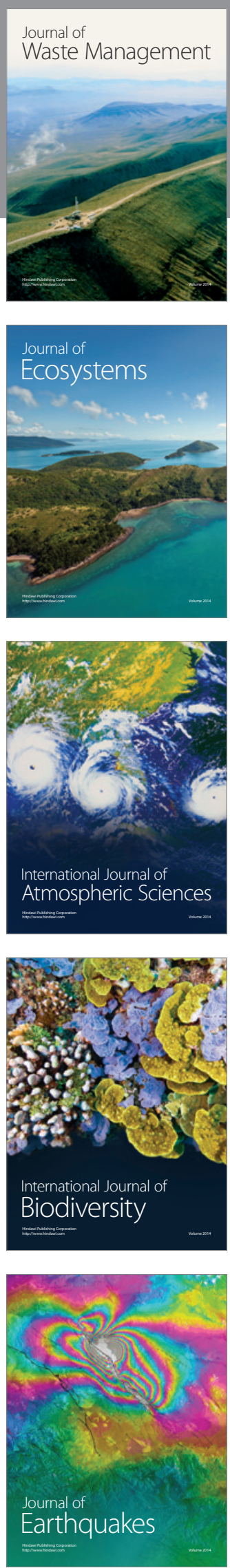
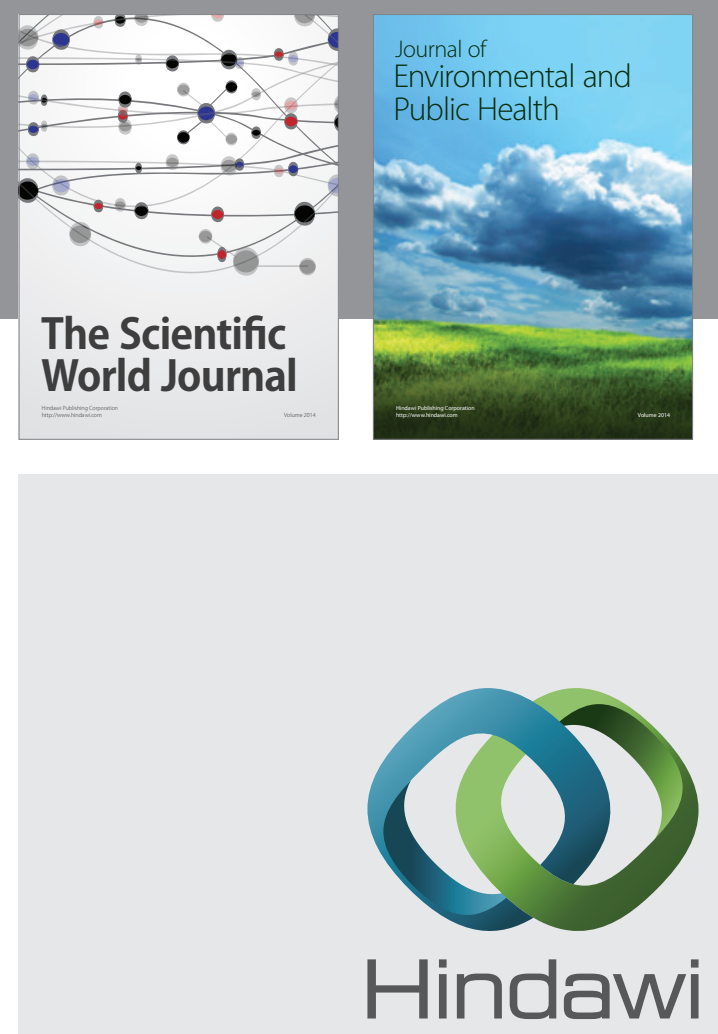

Submit your manuscripts at

http://www.hindawi.com
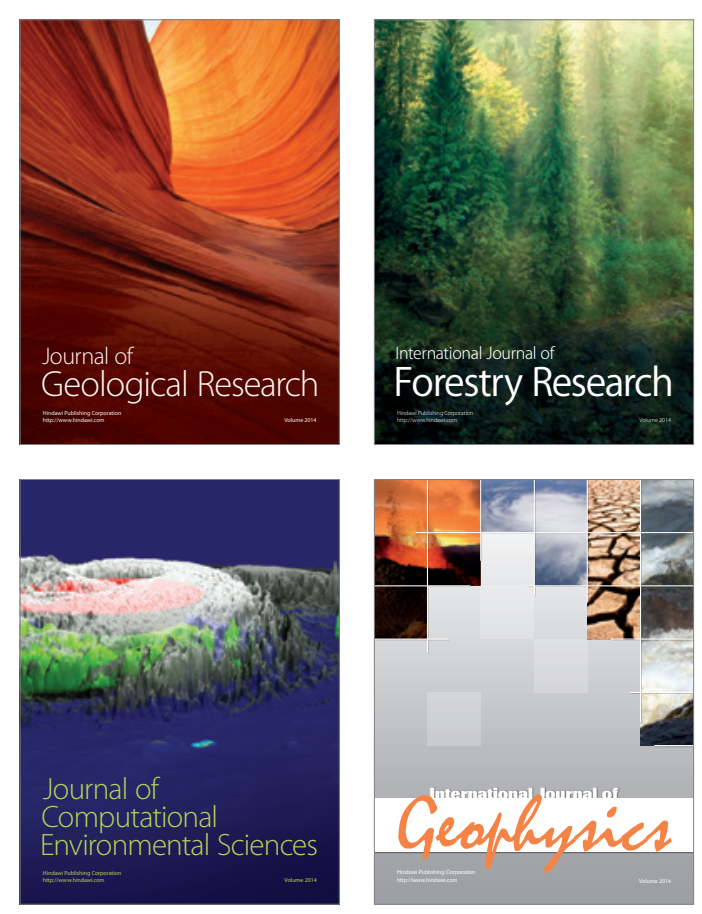
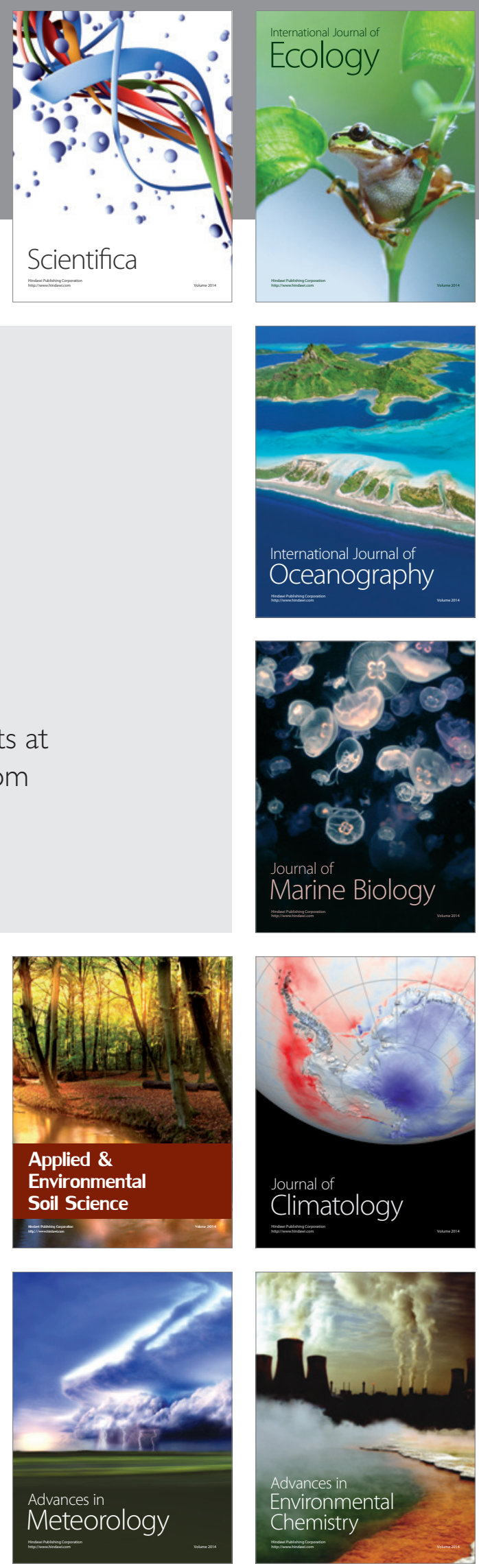